\title{
Food-dependent, exercise-induced anaphylaxis triggered by co-incidence of culprit food, physical effort and a very high dose of ibuprofen or menstruation: a case report
}

\author{
Krzysztof Gomułka', Anna Wolańczyk-Mędrala ${ }^{1}$, Wojciech Barg ${ }^{2}$, Wojciech Mędrala ${ }^{1}$
}

'Department of Internal Diseases and Allergology, Medical University of Wroclaw, Wroclaw, Poland ${ }^{2}$ Department of Physiology, Medical University of Wroclaw, Wroclaw, Poland

Adv Dermatol Allergol 2017; XXXIV (1): 87-88

DOI: https://doi.org/10.5114/ada.2017.65629

\begin{abstract}
Food-dependent exercise-induced anaphylaxis (FDEIA) is defined as anaphylaxis resulting from co-incidence of ingestion of sensitizing food and physical activity, while any of those factors alone does not cause any adverse reactions [1-4]. A pathophysiological mechanism of FDEIA still remains not fully elucidated. An IgE-dependent mechanism triggered by ingestion of culprit food and confirmed by positive skin prick tests and/or specific IgE antibodies seems to be unquestionable. The role of physical exercise is not so obvious. It is considered that exercising increases absorption of nutrients from gastrointestinal mucosa into the systemic circulation [3, 4]. This assumption is supported by the fact that alcohol or nonsteroidal anti-inflammatory drugs (NSAIDs) are able to amplify an exercise-induced effect $[5,6]$. In some individuals NSAIDs are able either to independently substitute exercise [7] or act as an ultimate third co-factor for exercise and food allergen in triggering FDEIA [5]. It has been also demonstrated that in some patients FDEIA symptoms occurr only during menstruation $[8,9]$. We describe a patient in whom FDEIA symptoms occur only if exercising and ingestion of culprit food are accompanied by either a very high dose of NSAIDs or menstruation.
\end{abstract}

A 30-year-old female patient with no history of significant diseases (including allergy) reported three episodes of anaphylaxis within past 5 years (Table 1). Allergy diagnostics showed a total IgE concentration elevated to $170 \mathrm{IU} / \mathrm{ml}(n<100 \mathrm{IU} / \mathrm{ml})$ in the ELISA assay. Serum concentrations of C3-, C4-complement proteins and C1-esterase inhibitor were within normal limits. Skin prick-tests with common inhalant and food allergens (Allergopharma, Reinbek, Germany) were positive for grass, oak, rye, birch, beech, alder, hazel, mugwort and plantain pollens, as well as for house dust mites, cat and dog fur and mold spores of Aspergillus, Cladosporium and Alternaria. Food prick-tests were positive for hen egg, tomato, hazelnut, celery and chamomile. An intradermal test with autologous serum was negative. Physical tests: a rub test for dermographism, compression test and thermal test with ice cube were also negative. A standard exercise test [10] produced neither signs of anaphylaxis nor changes in spirometric values. Oral provocation tests with acetylsalicylic acid and ibuprofen up to the total cumulative doses of $1200 \mathrm{mg}$ and $600 \mathrm{mg}$, respectively, were both negative and this excluded non-allergic hyperreactivity to NSAIDs as well as a selective allergy to ibuprofen. Double provocation with ibuprofen $200 \mathrm{mg}$ orally together with muesli and banana did not produce anaphylaxis, either. Challenge with food allergens, NSAIDs and exercise together was not performed due to a high risk of severe anaphylaxis.

Despite a negative history of allergy, the patient is highly hyper-responsive to common allergens, as shown in inhalant and food prick-tests. Noteworthy, a prick test with birch was $7 \times 7 \mathrm{~mm}$ and this allergen demonstrates potent cross-reactions with banana and plum. The first episode occurred when food allergens and exercise were accompanied by an unusually high daily dose of NSAID (ibuprofen, $1600 \mathrm{mg}$ ). The second and third episodes took place during menstruation. The most severe episode was induced with a very intensive exercise of long-distance race running. The patient reported to the race ambulance but the symptoms were misdiagnosed by paramedics and only oral antihistamines were administered. Consequently, the third event which occurred only 2 days later was triggered by a very little effort while the patient was not fully recovered from the previous episode and was still menstruating.

There is a notable feature in her FDEIA that "a classic combination" of sensitizing food and exercise does not produce anaphylactic symptoms. The patient regularly takes strenuous exercises (running, judo, fitness) after

Address for correspondence: Krzysztof Gomułka MD, PhD, Department of Internal Diseases and Allergology, Medical University of Wroclaw, 66 Marii Curie-Skłodowskiej St, 50-369 Wroclaw, Poland, phone: +48 7178425 28, e-mail: kgomulka@wp.pl Received: 11.12.2015, accepted: 22.04.2016. 
Table 1. Episodes of FDEIA

\begin{tabular}{|c|c|c|c|}
\hline Variable & Episode 1 & Episode 2 & Episode 3 \\
\hline Food eaten before exercise & Muesli, banana & $\begin{array}{l}\text { Dark bread, banana, plum jam, } \\
\text { honey }\end{array}$ & Muesli, honey, banana \\
\hline $\begin{array}{l}\text { Food allergen proved in skin } \\
\text { prick tests }\end{array}$ & Rye, hazelnut & Egg, rye & Rye, hazelnut \\
\hline $\begin{array}{l}\text { Nonsteroidal anti-inflammatory } \\
\text { drug }\end{array}$ & $\begin{array}{l}\text { Ibuprofen, } 400 \text { mg q.i.d., } \\
\text { ongoing for a few days }\end{array}$ & - & - \\
\hline $\begin{array}{l}\text { Time from the NSAID intake } \\
\text { to the onset of anaphylaxis }\end{array}$ & About $4 \mathrm{~h}$ & About $6 \mathrm{~h}$ & - \\
\hline $\begin{array}{l}\text { Physical effort and its } \\
\text { intensity }\end{array}$ & $\begin{array}{l}\text { Jogging; } \\
\text { medium intensity }\end{array}$ & $\begin{array}{c}\text { Fitness and then long-distance } \\
\text { running; high intensity }\end{array}$ & Walk; low intensity \\
\hline $\begin{array}{l}\text { Time from the start } \\
\text { of exercising to the onset } \\
\text { of anaphylaxis }\end{array}$ & About $15 \mathrm{~min}$ & About $15 \mathrm{~min}$ & About $30 \mathrm{~min}$ \\
\hline Symptoms of anaphylaxis & $\begin{array}{c}\text { Face angioedema, generalized } \\
\text { urticaria, dyspnea }\end{array}$ & $\begin{array}{l}\text { Face angioedema, generalized } \\
\text { urticaria, loss of consciousness }\end{array}$ & Face angioedema \\
\hline Treatment of anaphylaxis & Antihistamines & Antihistamines, calcium tablets & Antihistamines, calcium tablets \\
\hline
\end{tabular}

eating muesli with banana with no symptoms of FDEIA and this is coherent with negative outcomes of the provocations in vivo. All three FDEIAs occurred when ingestion of the culprit food and exercising was accompanied by either an unusually high dose of NSAID or menstruation. Thus, we assume that her third potent cofactor is an ultimate condition for triggering FDEIA. This case emphasizes that a carefully and thoroughly taken medical history is of crucial importance, otherwise FDEIA can easily be unrecognized.

\section{Conflict of interest}

The authors declare no conflict of interest.

\section{References}

1. Maulitz RM, Pratt DS, Schocket AL. Exercise-induced anaphylactic reaction to shellfish. J Allergy Clin Immunol 1979; 63: 433-4.

2. Mobayed HM, Ali Al-Nesf M. Two cases of food-dependent exercise-induced anaphylaxis with different culprit foods. Ann Thorac Med 2014; 9: 42-4.

3. Barg W, Medrala W, Wolanczyk-Medrala A. Exercise-induced anaphylaxis: an update on diagnosis and treatment. Curr Allergy Asthma Rep 2011; 11: 45-51.

4. Asaumi T, Yanagida N, Sato S, et al. Provocation tests for the diagnosis of food-dependent exercise-induced anaphylaxis. Pediatr Allergy Immunol 2016; 27: 44-9.

5. Harada S, Horikawa T, Ashida M, et al. Aspirin enhances the induction of type I allergic symptoms when combined with food and exercise in patients with food-dependent exerciseinduced anaphylaxis. Br J Dermatol 2001; 145: 336-9.

6. Medrala W, Barg W, Radlinska A, et al. Aspirin does not preferentially potentiate IgE-dependent basophil CD63 upregulation in patients with food-dependent exerciseinduced anaphylaxis. I Investig Allergol Clin Immunol 2015; 25: 68-70.
7. Matsukura S, Aihara M, Sugawara M, et al. Two cases of wheat-dependent anaphylaxis induced by aspirin administration but not by exercise. Clin Exp Dermatol 2010; 35: 233-7.

8. Bito T, Kanda E, Tanaka M, et al. Cow's milk-dependent exercise-induced anaphylaxis under the condition of a premenstrual or ovulatory phase following skin sensitization. Allergol Int 2008, 57: 437-9.

9. Fischer J, Schuck E, Biedermann T. Wheat-dependent exercise-induced anaphylaxis exclusively during menstruation. Allergy 2010; 10: 1347-8.

10. Anderton RC, Cuff MT, Frith PA, et al. Bronchial responsiveness to inhaled histamine and exercise. J Allergy Clin Immunol 1979; 63: 435-40. 